\title{
EVOLUTIONARY STRATEGY $(\mu+\lambda)$ AS AN INSTRUMENT FOR DETERMINING DEFORMATION PARAMETERS OF STEEL STRUCTURES
}

\author{
Maria Mrówczyńska \\ Department of Land and Environment Engineering \\ Institute of Building Engineering \\ University of Zielona Gora, Poland
}

\begin{abstract}
The article presents the use of an evolutionary algorithm for determining the shape of the guy rope sag of a steel smokestack. The author excludes the analysis of the operation of the rope, and discusses only the problem of determining parameters of the function of the adaption of the rope sag curve into empirical data, obtained by the geodetic method. The estimation of parameters of the curve and the characteristics of the accuracy of its adaption into experimental data were carried out by means of an evolutionary algorithm with the use of an evolutionary strategy $(\mu+\lambda)$.

The correctness of the strategy presented in the paper, as an instrument for searching for a global minimum of a criterion function, has been presented using as an example the minimisation of a certain two dimensional function and the estimation of parameters of an ordinary and orthogonal regression function. Previous theoretical analyses have also been used for determining parameters of the guy rope sag of a steel smokestack, which is measured periodically. In addition approximate values of the pull forces in the guy ropes have been calculated.
\end{abstract}

Keywords: evolutionary algorithms, regression.

\section{Introduction}

Evolutionary algorithms, also called evolutionary calculation techniques, are besides genetic algorithms and evolutionary programming, one of the three directions of development of so called simulated evolution, and they are used as methods of solving different problems in sciences, mainly optimisation tasks (Arabas, 2001). Procedures of an optimization strategy work on the basis of natural evolution and have their peculiar genetic material containing information about them, which 
participates in conveying traits to the next generations. Traits are recorded in genes, which are stored in chromosomes, and these are part of genetic material called a genotype. The conveyance of traits takes place during the process of recombination, i.e. the changing of genes under the influence of genetic operators i.e. crossing and mutations. Evolutionary strategies regarded as evolutionary programmes operate in the representation of chromosomes with a variable position in the form of real numbers (Gwiazda, 2007). One of the evolutionary strategies which can be used is the strategy $(\mu+\lambda)$. This algorithm helps to avoid a final solution in the form of a local minimum because it has a specific and large number of $\mu$ individuals of the parent population $\mathrm{P}$. This initial assumption guarantees a high variety of genotypes. A very similar strategy and also possible to use is the strategy $(\mu, \lambda)$. This method is different from the strategy $(\mu+\lambda)$ because in it individuals from the previous parent population do not move to a new batch and for this reason the population is not dominated by individuals with a high value of the adaptation function (Rutkowski, 2009).

\section{Optimization problem and evolutionary algorithms}

In subject literature (Goldberg, 2003; Rutkowski, 2009 there are three kinds of methods of searching for optimum solutions: analytical methods, survey methods and random methods. In analytical methods we search for local minima of a function solving systems of non-linear equations or following the negative direction of the gradient of an objective function. These methods are local in character, because a solution is searched for in the vicinity of a particular point. The application of these methods requires knowledge of derivatives of the objective function, which is impossible in practical applications when the function is discontinuous.

In survey methods it is assumed that the minima of a function are searched for by calculating its value in all the points in space, which considerably decreases the evaluation of the efficiency of the method because the search space is huge (Rutkowski, 2009). In random methods space is searched at random and the best solutions are recorded. Hence the conclusion is drawn that the range of application of the abovementioned methods is limited.

Evolutionary algorithms are a method of solving problems, based on natural evolution, which treats random selection merely as an instrument that helps to find solutions in a coded space of solutions. They are different from traditional optimization methods because of the following components, which influence the immunity of the algorithm and the resultant advantage over traditional methods (Arabas, 2001):

- evolutionary algorithms do not directly process parameters of a task, but their coded form,

- evolutionary algorithms carry out searches starting not from a single point but from a certain population,

- evolutionary algorithms use only the basic form of an objective function, without the necessity to determine its derivatives or other auxiliary information,

- evolutionary algorithms use probabilistic and not deterministic selection rules. 
Evolutionary algorithms, because of the advantages presented, can also be used for solving problems in the area of geodesy. Examples of applications mainly include transformations of coordinates (Civicioglu, 2012) and an optimum design of geodetic networks (Vajedian \& Bagheri, 2010).

\section{Evolutionary strategy $(\mu+\lambda)$}

An advantage of the evolutionary strategy $(\mu+\lambda)$ is the minimization of the probability of achieving the final solution in the form of a local minimum. We start an algorithm by randomly generating an initial parent population $\mathbf{P}$ with $\mu$ members. Then, by means of recombination procedures, a population $\mathbf{T}$ is created, which contains $\lambda$ members, and $\lambda \geq \mu$. In the next step we randomly select $\lambda$ members from the population $\mathbf{P}$ and place the members selected in the temporary population $\mathbf{T}$. Members of the temporary population $\mathbf{T}$ are crossed and mutated, as a result a population $\mathbf{O}$ is created with $\lambda$ members. In the final step the best offspring $\mu$ are selected from both populations $\mathbf{P} \cup \mathbf{O}$, which will become a new parent population $\mathbf{P}$. A block diagram of the evolutionary strategy $(\mu+\lambda)$ is presented in Fig. 1.

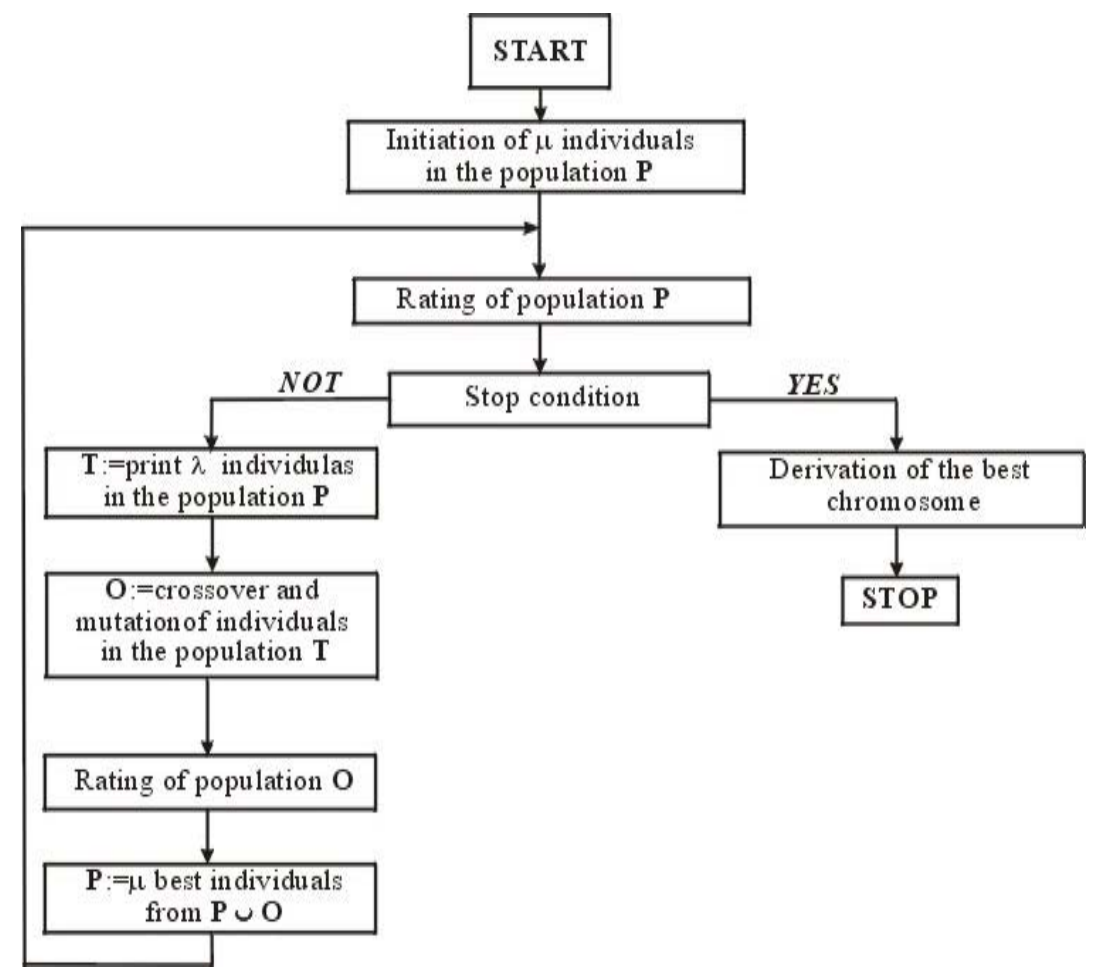

Fig. 1. Block diagram of the evolutionary strategy $(\mu+\lambda)$ (Rutkowski, 2009)

How the evolutionary strategy works is exemplified by the minimization of a function (Rutkowski, 2009)

$$
f\left(x_{1}, x_{2}\right)=x_{1}^{2}+x_{2}^{3}
$$

the following restrictions are assumed $-1 \leq x_{1} \leq 1$ and $-1 \leq x_{2} \leq 1$. The diagram of the function (1) is presented in Fig.2. 


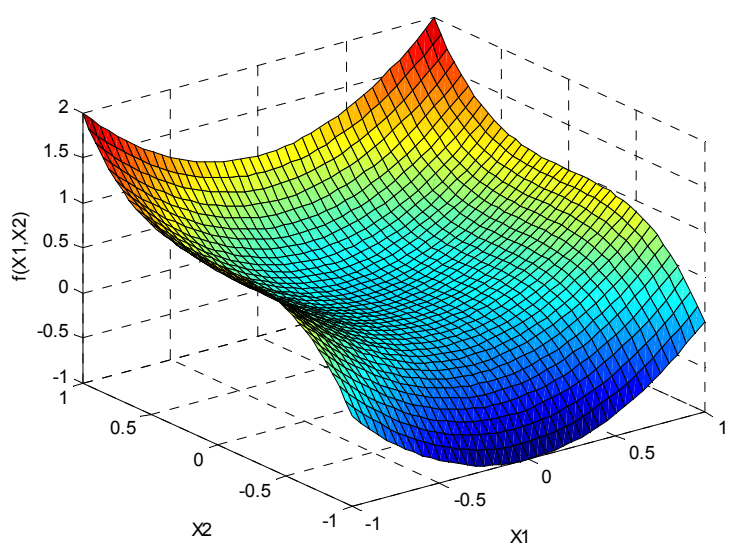

Fig. 2. Diagram of the two dimensional function (1)

We will assume the following parameters of the algorithm $\lambda=\mu=4$, and we will assume that only a mutation operator will be used. The adaption of members to the population will be determined by the adaption function (1), and we will regard as the best adapted those, for which the value of the function will be the smallest.

In the first step of the algorithm a population $\mathbf{P}$ was generated, consisting of $\mu=4$ randomly generated members, represented be the two-element vectors $\mathbf{x}=\left[x_{1}, x_{2}\right]^{\mathrm{T}}$ and $\boldsymbol{\sigma}=\left[\sigma_{1}, \sigma_{2}\right]^{\mathrm{T}}$ (we assume that $\left.\sigma_{1}=\sigma_{2}=1\right)($ Table 1$)$.

Table 1. Parent population $\mathbf{P}$

\begin{tabular}{|l|c|c|c|c|c|}
\hline $\begin{array}{c}\text { Number } \\
\text { of } \\
\text { individual }\end{array}$ & $x_{1}$ & $x_{2}$ & $\sigma_{1}$ & $\sigma_{2}$ & $f\left(x_{1}, x_{2}\right)$ \\
\hline 1 & 0,43 & $-0,65$ & 1 & 1 & $-0,09$ \\
\hline 2 & $-0,62$ & $-0,85$ & 1 & 1 & $-0,23$ \\
\hline 3 & 0,32 & 0,12 & 1 & 1 & 0,10 \\
\hline 4 & 0,51 & 0,39 & 1 & 1 & 0,32 \\
\hline
\end{tabular}

It is easy to notice that in the case of chromosomes 1 and 2 the value of the adaption function is the smallest. Another step in the operation of the algorithm is the creation by reproduction of a temporary population $\mathbf{T}$ of $\lambda=4$. Reproduction is $\mathbf{a}$ result of a random selection of $\lambda$ individuals from the population $\mathbf{P}$ (random sampling with replacement) in order to create the temporary population $\mathbf{T}$ (Table 2). Let us notice that chromosomes designated with 1, 2 and 3 joined the population $\mathbf{T}$.

Table 2. Temporary population $\mathbf{T}$

\begin{tabular}{|c|c|c|c|c|c|}
\hline $\begin{array}{c}\text { Number } \\
\text { of } \\
\text { individua } \\
\text { I }\end{array}$ & $x_{1}$ & $x_{2}$ & $\sigma_{1}$ & $\sigma_{2}$ & $f\left(x_{1}, x_{2}\right)$ \\
\hline 1 & 0,32 & 0,12 & 1 & 1 & 0,10 \\
\hline 2 & 0,43 & $-0,65$ & 1 & 1 & $-0,09$ \\
\hline 3 & $-0,62$ & $-0,85$ & 1 & 1 & $-0,23$ \\
\hline 4 & 0,43 & $-0,65$ & 1 & 1 & $-0,09$ \\
\hline
\end{tabular}


Then, individuals from the population $\mathbf{T}$ undergo genetic operations in the form of the mutation of chromosome $\sigma$ and change in the value of chromosome $\times$ (Table 3 and Table 4). A single individual is subjected to the mutation procedure (changing information contained in the genotype of an individual). First, chromosome $\boldsymbol{\sigma}=\left[\sigma_{1}, \sigma_{2}\right]^{\mathrm{T}}$ is mutated, according to the dependence

$$
\sigma_{i}^{\prime}=\sigma_{i} \exp \left(\tau^{\prime} N(0,1)+\tau N_{i}(0,1)\right)
$$

where: $i=1,2, \ldots, n, n$ - chromosome length, $N(0,1)$ - random number from the normal distribution of single sampling for the whole chromosome, $N_{i}(0,1)$ - random number from the normal distribution of sampling for each gene, $\tau$ and $\tau^{\prime}$ - parameters of evolutionary strategies, which influence the achievement of convergence of the algorithm to the solution. Values of the parameters are obtained from the formulae:

$$
\tau^{\prime}=\frac{C}{\sqrt{2 n}}, \tau=\frac{C}{\sqrt{2 \sqrt{n}}}
$$

where the invariable $C$ in most cases assumes the value 1.

Table 3. Mutation of chromosome $\sigma$ of particular individuals in the population $\mathbf{T}$

\begin{tabular}{|c|c|c|c|c|c|c|c|c|c|}
\hline $\begin{array}{c}\text { Number } \\
\text { of } \\
\text { individu } \\
\text { al }\end{array}$ & $\mathrm{N}(0,1)$ & $\sigma_{1}$ & $\mathrm{~N}_{1}(0,1)$ & $\begin{array}{l}\exp \left(\tau^{\prime} \mathrm{N}(0,1)+\right. \\
\left.\tau \mathrm{N}_{1}(0,1)\right)\end{array}$ & $\sigma_{1}^{\prime}$ & $\sigma_{2}$ & $\mathrm{~N}_{2}(0,1)$ & $\begin{array}{l}\exp \left(\tau^{\prime} \mathrm{N}(0,1)+\right. \\
\left.\tau \mathrm{N}_{2}(0,1)\right)\end{array}$ & $\sigma_{2}^{\prime}$ \\
\hline 1 & 0,15 & 1 & $-0,42$ & 0,84 & 0,84 & 1 & $-0,45$ & 0,82 & 0,82 \\
\hline 2 & $-0,54$ & 1 & 0,75 & 1,19 & 1,19 & 1 & $-1,06$ & 0,41 & 0,41 \\
\hline 3 & $-0,73$ & 1 & $-1,02$ & 0,38 & 0,38 & 1 & 0,95 & 1,22 & 1,22 \\
\hline 4 & 0,41 & 1 & 1,63 & 3,24 & 3,24 & 1 & $-0,24$ & 1,06 & 1,06 \\
\hline
\end{tabular}

In the following step, on the basis of the calculation of new ranges of the mutation $\sigma_{i}^{\prime}$, we will determine subsequent values of chromosomes $x_{i}$ (Table 4), according to the dependence

$$
x_{i}^{\prime}=x_{i}+\sigma_{i}^{\prime} N_{i}(0,1)
$$

where $N_{i}(0,1)$ represents the random value of the normal distribution, $i=1, \ldots, n$.

Table 4. Mutation of chromosome $\mathbf{x}$ of particular individuals of the population $\mathbf{T}$

\begin{tabular}{|c|c|c|c|c|c|c|c|c|}
\hline \multirow{2}{*}{$\begin{array}{c}\text { Number } \\
\text { of } \\
\text { individual }\end{array}$} & \multicolumn{4}{|c|}{ Gen 1 } & \multicolumn{4}{c|}{ Gen 2 } \\
\cline { 2 - 9 } & $x_{1}$ & $\mathrm{~N}_{1}(0,1)$ & $\sigma_{1}^{\prime} \mathrm{N}_{1}(0,1)$ & $x_{1}^{\prime}$ & $x_{2}$ & $\mathrm{~N}_{2}(0,1)$ & $\sigma_{2}^{\prime} \mathrm{N}_{2}(0,1)$ & $x_{2}^{\prime}$ \\
\hline 1 & 0,32 & $-0,45$ & $-0,38$ & $-0,06$ & 0,12 & 1,12 & 0,92 & 1,04 \\
\hline 2 & 0,43 & 0,21 & 0,25 & 0,68 & $-0,65$ & 0,89 & 0,36 & $-0,28$ \\
\hline 3 & $-0,62$ & 1,35 & 0,51 & $-0,11$ & $-0,85$ & $-0,23$ & $-0,28$ & $-1,13$ \\
\hline 4 & 0,43 & $-0,05$ & $-0,16$ & 0,27 & $-0,65$ & 0,17 & 0,18 & 0,47 \\
\hline
\end{tabular}


After the genetic operations we obtain the offspring population $\mathbf{0}$ containing the chromosomes presented in Table 5.

Table 5. Offspring population 0

\begin{tabular}{|c|c|c|c|c|c|}
\hline $\begin{array}{c}\text { Number } \\
\text { of } \\
\text { individual }\end{array}$ & $x_{1}$ & $x_{2}$ & $\sigma_{1}$ & $\sigma_{2}$ & $f\left(x_{1}, x_{2}\right)$ \\
\hline 1 & $-0,06$ & 0,12 & 0,84 & 0,82 & 0,01 \\
\hline 2 & 0,68 & $-0,65$ & 1,19 & 0,41 & 0,19 \\
\hline 3 & $-0,11$ & $-0,85$ & 0,38 & 1,22 & $-0,60$ \\
\hline 4 & 0,27 & $-0,65$ & 3,24 & 1,06 & $-0,20$ \\
\hline
\end{tabular}

According to the operation rule of the strategy $(\mu+\lambda)$ a new parent population $\mathbf{P}$ is created from the best chromosomes of the previously generated population $\mathbf{P}$ and the current population $\mathbf{O}$ (Table 6).

It is worth noting that for the best individual in the new population the values $x_{1}$ and $x_{2}$ are close to an optimum solution. Simultaneously, the values of the components $\sigma_{1}$ and $\sigma_{2}$ corresponding to the best individual are clearly smaller than the ones initially assumed. A narrow mutation range enabled a more precise solution and decreased the area of the searched space.

Table 6. New parent population $\mathbf{P}$

\begin{tabular}{|c|l|c|c|c|c|}
\hline $\begin{array}{c}\text { Number } \\
\text { of } \\
\text { individual }\end{array}$ & $x_{1}$ & $x_{2}$ & $\sigma_{1}$ & $\sigma_{2}$ & $f\left(x_{1}, x_{2}\right)$ \\
\hline 1 & $-0,06$ & 0,12 & 0,84 & 0,82 & 0,01 \\
\hline 2 & 0,43 & $-0,65$ & 1 & 1 & $-0,09$ \\
\hline 3 & 0,32 & 0,12 & 1 & 1 & 0,10 \\
\hline 4 & 0,68 & $-0,65$ & 1,19 & 0,41 & 0,19 \\
\hline
\end{tabular}

Another strategy used is the strategy $(\mu, \lambda)$, the operation of which is almost identical to the strategy $(\mu+\lambda)$. The strategy merely requires that the condition $\mu>\lambda$ should be satisfied, because the new population $\mathbf{P}$ with $\mu$ individuals is created of the best $\lambda$ individuals of the population $\mathbf{O}$.

Another example of a task solved by means of an evolutionary algorithm is a search for a minimum of the two dimensional Ackley function (Rutkowski, 2009)

$$
f\left(x_{1}, x_{2}\right)=-20 \exp \left(-0,2 \sqrt{0,5\left(x_{1}^{2}+x_{2}^{2}\right)}-\exp \left(0,5 \cos \left(2 \pi x_{1}\right)+\cos \left(2 \pi x_{2}\right)\right)+20+e\right.
$$

It results from the form of the function (5) and its diagram (Fig. 3) that the function reaches a global minimum $f(\mathbf{x})=0$ at the point $\mathbf{x}=0$. Assuming that the number of variables is $n=2$ with the restrictions $-5,0 \leq x_{i} \leq 5,050$ values of the initial population were generated. After 50 generations had been carried out closeness to the value of the minimum searched for was achieved in the form of the adaption function $f\left(x_{1}, x_{2}\right)=0,0188$ for $x_{1}=-0,0052$ and $x_{2}=-0,0034$. 
The example should be complemented with the remark that in the following steps of the algorithm information about the previous best solution is lost, which prevents the algorithm from getting stuck in a local minimum.

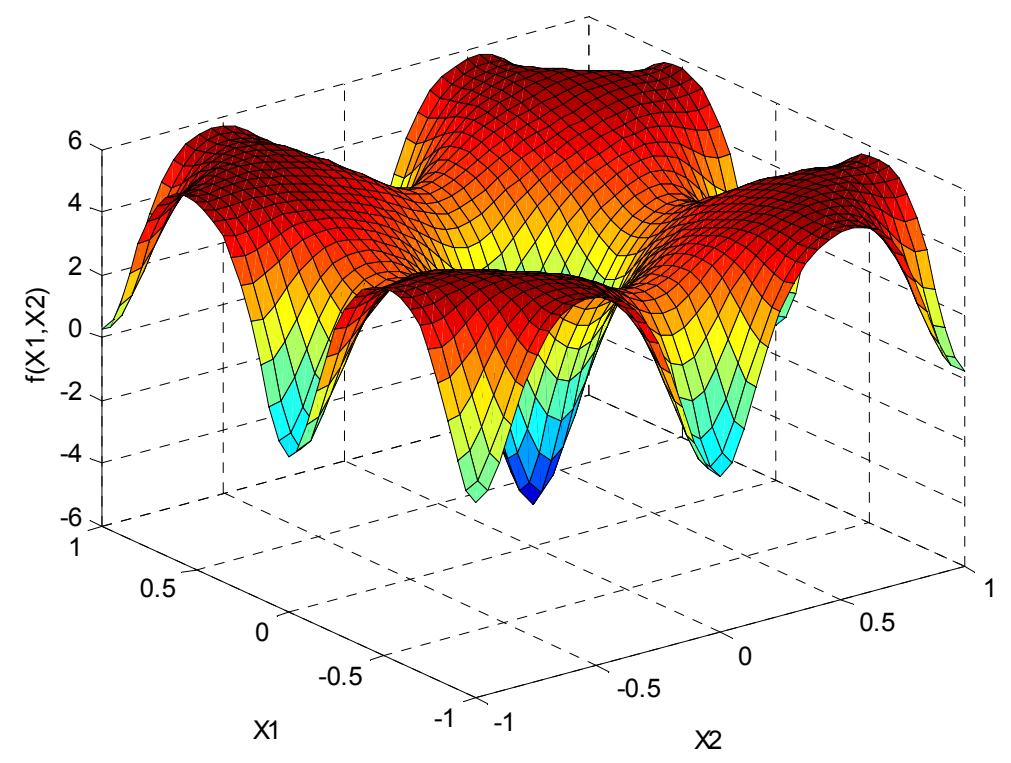

Fig. 3. Diagram of the two-dimensional Ackley function (5)

\section{Application of evolutionary strategies}

The correctness and effectiveness of the operation of evolutionary algorithms were checked by using as an example measurements of the shape of the sag of the guy ropes of an 80 meter high steel smokestack. The shape of the sag of the rope under its own weight is described by a chain curve (catenoid) expressed with the equation (Adamczewski, 1992)

$$
y=k \cosh \left(\frac{x+a}{k}\right)-b \quad(k>0) .
$$

where:

- $\quad k$ - geometric parameter of the curve, used for calculating the pull force in the string,

- $a, b$ - invariables of the translation of the beginning of the system of coordinates $x o y$ in relation to the beginning the system of measurement coordinates XOY (Fig. 3).

The task consists in estimating parameters of the regression curve (chain curve) when the condition $\left[v_{y}^{2}\right]=$ min. is satisfied (ordinary regression).

The parameter $k$ determines the shape of the chain curve and is the basis for calculating an approximate value of the horizontal component of the pull force of the rope $\mathrm{H}$ (the same at all the points of the rope), which is directly proportional to the unit weight of the rope $q=7850\left[\mathrm{~kg} / \mathrm{m}^{3}\right]^{*}$ area of the cross-section of the rope $\left[\mathrm{m}^{2}\right]$ and the parameter $k$ (Jaśkiewicz et al. 2000) according to the dependence

$$
H=q k
$$




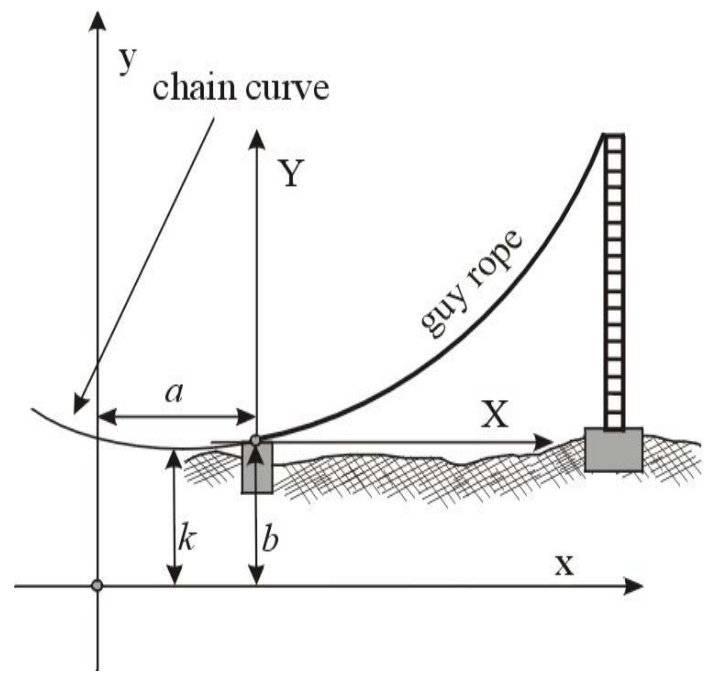

Fig. 3. Shape of the guy rope sag curve

It should be noted that the possible accuracy of the adaption of the chain curve depends on how accurately the position of points on the axis of the string is determined, and the assumed form of the adaption function (Janusz, 1995,1996). Periodical measurements were carried out in order to determine sag and deviation arrows for each three ropes stabilizing the position of the smokestack in three directions determined by three guy ropes. A set of five points located on the axis of each of the three ropes resulted from the measurements. Of course, if necessary, more measurement points can be located on the cables.

The values of coordinates for one of the guy ropes (the component $\mathrm{x}$ is regarded as deterministic) are presented in Table 7.

Table 7. List of the coordinates of points located on the guy ropes I

\begin{tabular}{|c|c|c|c|}
\hline $\begin{array}{c}\text { Number of the } \\
\text { ponit }\end{array}$ & $x[\mathrm{~m}]$ & $\mathrm{y}[\mathrm{m}]$ & $\mathrm{m}_{\mathrm{y}}[\mathrm{m}]$ \\
\hline & \multicolumn{3}{|c|}{ Upper line } \\
\hline 1 & 0,00 & $-1,43$ & 0,00 \\
\hline 2 & 9,54 & 15,88 & 0,01 \\
\hline 3 & 19,02 & 33,62 & 0,02 \\
\hline 4 & 28,53 & 51,74 & 0,04 \\
\hline 5 & 38,17 & 70,80 & 0,05 \\
\hline \multicolumn{3}{|c|}{ Center line } \\
\hline 1 & 0,00 & $-1,65$ & 0,00 \\
\hline 2 & 9,13 & 10,30 & 0,01 \\
\hline 3 & 18,61 & 23,08 & 0,02 \\
\hline 4 & 28,12 & 36,10 & 0,03 \\
\hline 5 & 37,70 & 49,72 & 0,04 \\
\hline \multicolumn{3}{|c|}{ Bottom line } \\
\hline 1 & 0,00 & $-1,66$ & 0,00 \\
\hline 2 & 7,42 & 5,44 & 0,00 \\
\hline 3 & 14,87 & 12,80 & 0,01 \\
\hline 4 & 22,40 & 20,31 & 0,01 \\
\hline 5 & 30,29 & 28,63 & 0,02 \\
\hline
\end{tabular}


The adaption of the chain curve was compared with a $2^{\text {nd }}$ degree polynomial of a similar shape $y=a_{0}+a_{1} x+a_{2} x^{2}$ (Koronowski, 1982). Results of the operation of the evolutionary algorithm and approximation with a parabola are presented in Table 8 and Fig. 4. For clearness' sake the data presented in Fig. 4 have been adequately scaled.

Table 8. Approximation results for guy rope I

\begin{tabular}{|l|l|l|l|l|l|l|l|l|}
\hline \multicolumn{2}{|l|}{ Evolutionary strategy $(\mu+\lambda)$} & \multicolumn{3}{l|}{ Polynomial 2nd stage } \\
\hline$a$ & $b$ & $k$ & $m_{\text {apr }}[\mathrm{m}]$ & $a_{0}$ & $a_{1}$ & $a_{2}$ & $m_{\text {apr }}[\mathrm{m}]$ \\
\hline \multicolumn{7}{|c|}{ Upper line } \\
\hline 477,91 & 729,10 & 356,63 & 0,062 & $-1,42196$ & 1,78836 & 0,00270 & 0,051 \\
\hline \multicolumn{8}{|c|}{ Center line } \\
\hline 431,28 & 658,41 & 403,60 & 0,048 & $-1,64474$ & 1,29194 & 0,00186 & 0,042 \\
\hline \multicolumn{8}{|c|}{ Bottom line } \\
\hline 272,34 & 448,54 & 326,65 & 0,046 & $-1,64514$ & 0,93891 & 0,00197 & 0,060 \\
\hline
\end{tabular}

The horizontal component of the pull force $H$ for the upper, middle and bottom ropes in the guy rope I is respectively: $H_{u}=219,88 \mathrm{kN}, H_{m}=248,83 \mathrm{kN}, H_{b}=201,39 \mathrm{kN}$. The components of all the ropes in guy ropes I, II and III are presented in Table 9.

Table 9. Horizontal components $H$ of the pull force of the rope

\begin{tabular}{|c|c|c|c|}
\hline \multirow{2}{*}{$\begin{array}{c}\text { Number of the guy } \\
\text { rope }\end{array}$} & \multicolumn{3}{|c|}{ Horizontal components $H$ [kN] of the pull force for } \\
\cline { 2 - 4 } & upper line & center line & bottom line \\
\hline I & 219,88 & 248,83 & 201,39 \\
\hline II & 249,52 & 241,80 & 222,24 \\
\hline III & 248,86 & 279,14 & 197,14 \\
\hline
\end{tabular}

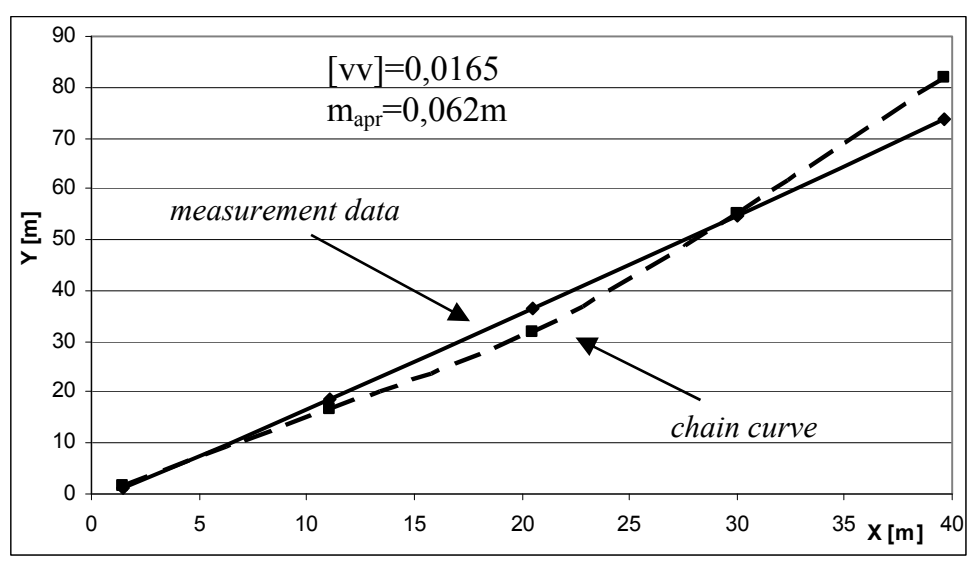

Fig. 4. Adaption of the chain curve into an empirical set of points (upper line)

In order to obtain satisfying results of the approximation of parameters of the chain curve with the use of the evolutionary strategy, it is necessary to adopt a vast parent population (250 individuals) and to perform a large number of iterations (generations). For this reason, it is not possible to show particular stages of the evolutionary algorithm in the article. The variation of changes of values of the best adaptation function for the whole population is presented in Fig. 5. 


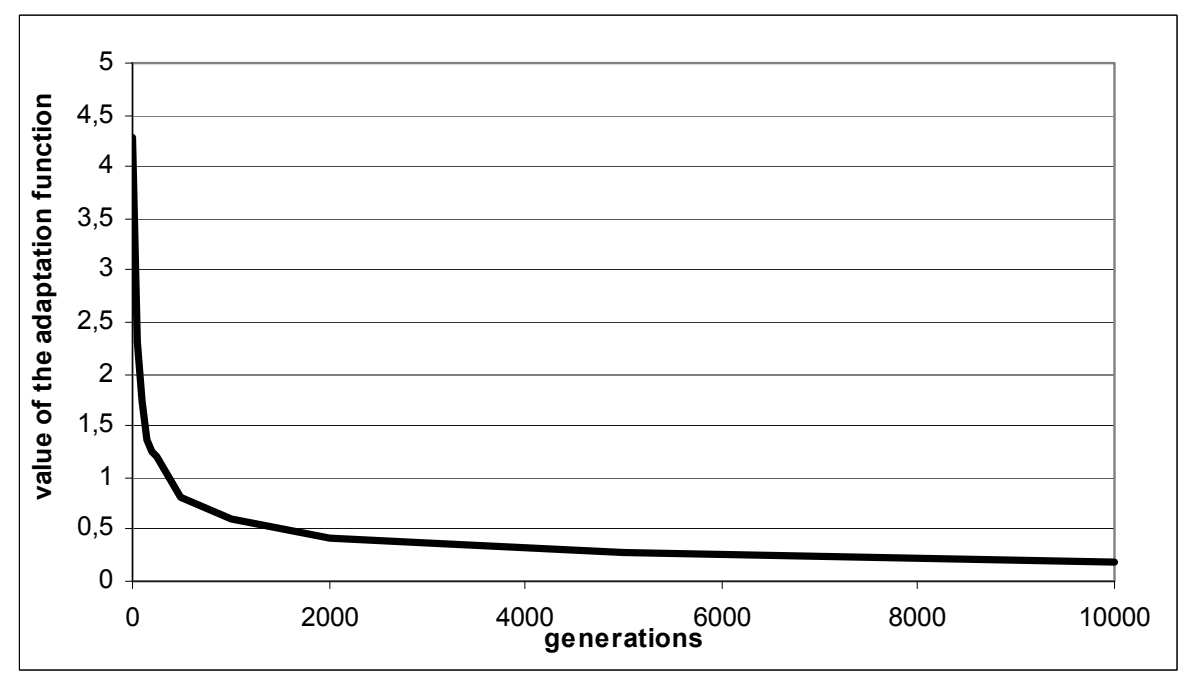

Fig. 5. Value of the adaptation function in consecutive generations

In applications in the field of economy, issues connected to nature and technology, where variables occur as physical values (e.g. time, temperature, measurement data) orthogonal regression is regarded as more important. The criterion of the optimization of the adaption of the orthogonal regression curve is the value of the sum of the squares of corrections of the measurement data $x, y$ (Janusz, 1995)

$$
v_{x}=\frac{\Delta x}{m_{x}}, v_{y}=\frac{\Delta y}{m_{y}} .
$$

in relations to the chain curve described with the equation

$$
y+\Delta y=k \cosh \left(\frac{x+\Delta x+a}{k}\right)-b .
$$

according to the assumption

$$
\left[v_{x}^{2}+v_{y}^{2}\right]=\min .
$$

Results of the calculations in the form of the parameter $k$ and the value of the pull force with the use of orthogonal regression and evolutionary algorithms as well as the assumption $m_{x}=m_{y}=5 \mathrm{~cm}$ are presented in Table 10. The graphical interpretation of the results obtained by means of ordinary and orthogonal regression has been adequately scaled and presented in Fig.6. 


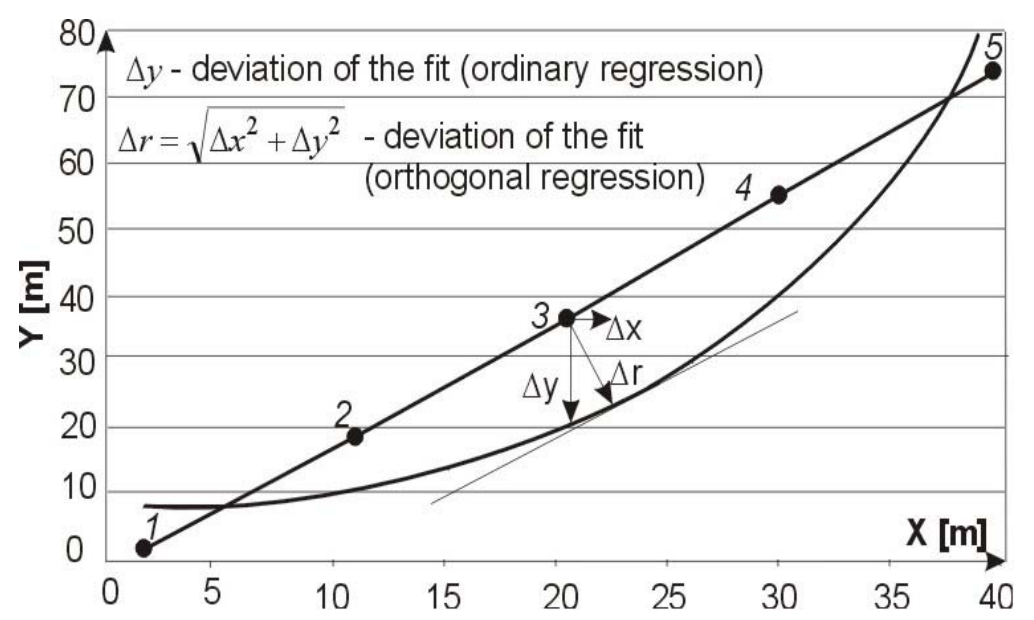

Fig. 6. Adaption deviations on the basis of the procedure of ordinary and orthogonal regression (upper line - guy rope I)

Table 10. Parameter $k$ of the chain curve and the pull force of the ropes

\begin{tabular}{|c|c|c|c|c|}
\hline \multicolumn{5}{|c|}{ The ordinary regression } \\
\hline \multirow{4}{*}{ 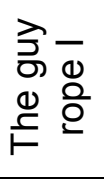 } & & $k$ & $H[\mathrm{kN}]$ & $m_{a p r}[\mathrm{~m}]$ \\
\hline & bottom line & 356,63 & 219,88 & 0,06 \\
\hline & center line & 403,60 & 248,83 & 0,05 \\
\hline & upper line & 326,65 & 201,39 & 0,05 \\
\hline \multicolumn{5}{|c|}{ The orthogonal regression } \\
\hline \multirow{4}{*}{$\begin{array}{l}\widehat{\bar{\sigma}} \bar{\Phi} \\
\Phi \\
\stackrel{0}{F}\end{array}$} & & $k$ & $H[\mathrm{kN}]$ & $m_{a p r}[\mathrm{~m}]$ \\
\hline & bottom line & 356,63 & 219,88 & 0,06 \\
\hline & center line & 403,60 & 248,83 & 0,05 \\
\hline & upper line & 326,66 & 201,40 & 0,05 \\
\hline
\end{tabular}

Figure 7 presents graphical results of approximate calculations of the value of the pull forces of particular ropes suspended in three directions of the guy ropes. The figure shows that the greatest pull force in terms of value occurs in the medium rope in the direction III of the guy ropes.

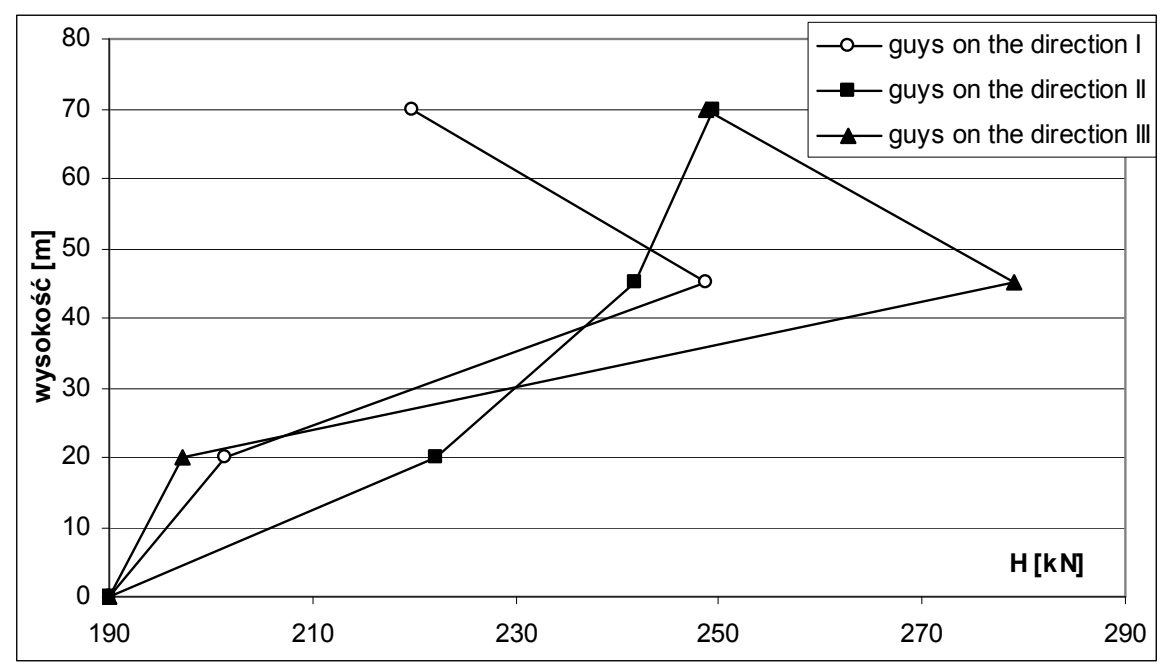

Fig. 7. Values of the pull forces in the ropes 


\section{Conclusions}

Evolutionary strategies are included into the most important methods of evolutionary calculations with the use of deterministic selection methods. The convergence theorem has been proved for evolutionary strategies (Arabas, 2001), which states that for a large number of searches a global optimum of the criterion optimized is obtained with a probability of 1 . However, on the basis of this theorem it is not possible to obtain information about the speed of the convergence of the algorithm towards the expected optimum solution, which is a certain drawback as far as the formulation of a condition for stopping the algorithm is concerned. The simplest method consists in generating a specified number of times new sets of parameters of the task as points in the search space. A drawback of this method is the inability to check the quality of the solution obtained. For this reason in most cases the operation of the algorithm is stopped when a satisfactory value of the adaption function defined is obtained (Łęski, 2008). Evolutionary algorithms are easy to use, because there are no restrictions on the criterion optimized.

Using evolutionary algorithms as an instrument for determining deformations of steel structures provides results which are not less accurate than those obtained by means of classical methods. It is also possible to notice that results of the adaption of the chain curve obtained by means of orthogonal regression are comparable with those obtained by means of ordinary regression.

\section{References}

Adamczewski, Z. (1992). Krzywa łańcuchowa jako linia realna. Przegląd Geodezyjny nr 4. Warszawa.

Arabas, J. (2001). Wykłady z algorytmów ewolucyjnych. Warszawa: Wydawnictwo Naukowo - Techniczne.

Civivioglu P. (2012). Transforming geocentric cartesian coordinates to geodetic coordinates by using differential search algorithm, Computers and Geosciences, Volume 46, pp. 229-247.

Goldberg, D. E. (2003). Algorytmy genetyczne $i$ ich zastosowanie. Warszawa: Wydawnictwo Naukowo - Techniczne.

Gwiazda, T. D. (2007). Algorytmy genetyczne. Kompendium. Warszawa: Wydawnictwo Naukowe PWN SA.

Janusz, J. (1995). Ortogonalne wpasowanie krzywej teoretycznej empiryczny zbiór punktów. Prace Instytutu Geodezji i Kartografii, tom XLII, z. 92. Warszawa.

Janusz. J. (1996). Metodyka geodezyjnego badania naprężeń i wydłużeń lin w konstrukcjach cięgnowych, Prace Instytutu Geodezji i Kartografii, tom XLIII, z. 94. Warszawa

Jaśkiewicz, M., Traczewski, W., Wynalek, J. \& Zaremba, S. (2000). Zastosowanie pomiarów geodezyjnych do diagnostyki lin, Zaszyty Naukowe Akademii Rolniczej we Wrocławiu, Geodezja i Urządzenia Rolne XVII, nr 394. Wrocław. 
Koronowski, R. (1982). Metoda określenia najprawdopodobniejszej krzywej aproksymującej wyniki szeregu obserwacji. Warszawa.

Łęski, J. (2008). Systemy neuronowo-rozmyte. Warszawa: Wydawnictwo Naukowo Techniczne.

Nowak, E. (2000). Algorytmy numeryczne w geodezji. Warszawa: Oficyna Wydawnicza Politechniki Warszawskiej.

Rutkowski, L. (2009). Metody i techniki sztucznej inteligencji. Warszawa: Wydawnictwo Naukowo -Techniczne.

Vajedian S. \& Bagheri H., (2010), Optimal design of geodetic network using genetic algorithm, EGU General Assembly Conference Abstract, Volume 12, pp. 14654, Vienna, Austria.

\section{Authors:}

dr hab. inż. Maria Mrówczyńska, m.mrowczynska@ib.uz.zgora.pl

Department of Land and Environment Engineering,

Institute of Building Engineering,

University of Zielona Gora,

1 Szafrana St., 65-516 Zielona Gora, Poland 